Available online on 15.5.2018 at http://ujpr.org
Universal Journal of Pharmaceutical Research
An International Peer Reviewed Journal
Open access to Pharmaceutical research

\title{
WOUND DRESSINGS UPLOADED WITH MYRTLE BERRIES EXTRACT AND NIGELLA SATIVA HONEY \\ Zam Wissam $^{1 *}$, Hammadi Maher ${ }^{2}(\mathbb{D})$ \\ ${ }^{I}$ Department of Analytical and Food Chemistry, Faculty of Pharmacy, Al-Andalus University for Medical Sciences, Tartous, Syrian Arab Republic. \\ ${ }^{2}$ Department of Analytical and Food Chemistry, Faculty of Pharmacy, Tartous University, Tartous, Syrian Arab Republic.
}

\section{ABSTRACT}

Objective: Wound dressings are frequently developed by introducing new products to target different aspects of the wound healing process. Many medicated dressings incorporated with natural extracts and chemicals have been developed. Chronic wounds could be invaded by many bacteria and Pseudomonas aeruginosa and Staphylococcus aureus are the most common. $S$. aureus and $P$. aeruginosa are usually detected in the higher layer of wounds or in the deepest region of wound bed, respectively. They can express many virulence factors affecting wound healing process and leading to severe infections and antibiotic resistance.

Methods: Starch based impregnated gauze containing either N. sativa honey, myrtle berries hydro-alcoholic extract or a combination were prepared. There efficacy against both $P$. aeruginosa and $S$. aureus isolated from chronic wounds.

Results: $N$. sativa honey mixture was the most potent against $P$. aeruginosa with an inhibition zone diameter of $18.1 \pm 0.3 \mathrm{~mm}$, while the myrtle berries hydro-alcoholic extract mixture was the most potent against $S$. aureus with an inhibition zone diameter of $18.4 \pm 0.5 \mathrm{~mm}$. The prepared impregnated gauzes deliver a moist environment that helps wounds epithelialize more rapidly.

Conclusion: In conclusion, honey and myrtle berries hydro-alcoholic extract provide antibacterial and anti-inflammatory properties that will accelerate the healing process of wounds.

Keywords: Myrtle berries hydro-alcoholic extract, N. sativa honey, Pseudomonas aeruginosa, Staphylococcus aureus, starch based impregnated gauzes.

Article Info: Received 3 March 2018; Revised 15 April; Accepted 8 May, Available online 15 May 2018

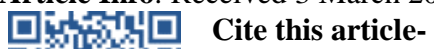

Wissam Z, Maher H. Wound dressings uploaded with myrtle berries extract and Nigella sativa honey. Universal Journal of Pharmaceutical Research 2018; 3(2): 11-14.

DOI: https://doi.org/10.22270/ujpr.v3i2.132

Address for Correspondence

Zam Wissam, Department of Analytical and Food Chemistry, Faculty of Pharmacy, Al-Andalus University for Medical Sciences, Tartous, Syrian Arab Republic. Tel.: +963-932-724703, E-mail: w.zam@au.edu.sy

\section{INTRODUCTION}

A wound is defined as a simple or severe break in an anatomical structure such as the skin and can outspread to other tissues ${ }^{1}$. Infection occurs in wounds due to competition with the host natural immune system and causes a delay in wound healing. The most common causes of infection are Staphylococcus aureus, Pseudomonas aeruginosa, Streptococcus pyogenes, and some Proteus, Clostridium, and Coliform species. The efficacy of topical solutions, creams or ointments for drug delivery to the wound is very low as they rapidly lose their rheological characteristics due to the absorption of fluids ${ }^{2}$. Traditionally, wound dressings are used to protect the wound from contamination ${ }^{3}$, but they can be developed to deliver bioactive molecules such as antimicrobial drugs to wound sites. Wound dressings uploaded with natural products, including the $\beta$-glucans, aloe, essential oils, honey, cocoa, and oak bark extracts are already being used in wound healing due to their antibacterial activity and wound healing properties ${ }^{4}$. Various parts of Myrtle (Myrtus communis L.) such as berries, fruits and leaves have been widely used as traditional medicine for the treatment of several diseases due to their anti-inflammatory, antioxidant and antimicrobial properties, ${ }^{5,6}$. Many components have been extracted from this herb and are considered to be the main biologically active components including polyphenols, myrtucommulone, semimyrtucommulone, $\alpha$-pinene, 1, 8-cineole, myrtenyl acetate, limonene, linalool and $\alpha$-terpinolene ${ }^{7}$. High antibacterial activity of ethanol, methanol, and ethyl acetate berry myrtle extracts was observed when tested against $S$. aureus, $P$. aeruginosa and Escherichia coli ${ }^{\mathbf{8} 9}$. Some results have indicated that phenolic compounds and tannins greatly contributed to the antibacterial efficacy ${ }^{10,11}$. In folk medicine, a decoction of leaves and fruits is used externally for wound healing ${ }^{12}$. Traditionally, honey has been considered to have therapeutic properties 
since ancient times ${ }^{13}$. Results of different researches had previously proved the efficacy of honey against different types of microbes depending on many factors such as the type, natural structure of the nectar and the environmental conditions ${ }^{14}$. Bacterial resistance is less likely to develop as a result of treatment with honey because of the composition of honey which contains a number of different components responsible for the antimicrobial efficacy ${ }^{\mathbf{1 5}}$. This includes $\mathrm{pH}$, sugar content, hydrogen peroxide levels and the presence of some phytochemicals, mainly phenolic compounds including phenolic acids and flavonoids ${ }^{16}$. Honey has also been proved to accelerate wound healing by offering antibacterial activity, maintaining a moist wound environment that promotes healing, and providing a protective barrier to prevent infection ${ }^{17,18}$. Many researchers report that honey could be an effective dressing for the treatment of different skin infections resulting from burns and wounds ${ }^{19,20}$.

In this study, the anti-bacterial effect of impregnated sterile gauzes containing myrtle berries extract and Nigella sativa honey was studied on both $P$. aeruginosa and S. aureus.

\section{MATERIALS AND METHODS}

Myrtle extracts preparation

Myrtle berries were collected from a mountainous region of Syria. $2 \mathrm{~g}$ of dried powders of myrtle berries were extracted by maceration in $100 \mathrm{ml}$ of ethanol $50 \%$ for 2 hours $^{21}$. The ethanol was evaporated using a rotary evaporator.

\section{Starch based gel preparation}

A starch based gel containing $20 \mathrm{~g}$ of starch, $20 \mathrm{ml}$ of glycerol, and $100 \mathrm{ml}$ of water was prepared first ${ }^{22}$. The solution was gently stirred until starch dissolved. It was then homogenized, heated for about $15 \mathrm{~min}$ at $80-85^{\circ} \mathrm{C}$ and finally cooled to room temperature. Three different mixtures were prepared using $10 \mathrm{ml}$ of the starch based gel with $10 \mathrm{ml}$ of $N$. sativa honey (purchased directly from beekeepers), $10 \mathrm{ml}$ of myrtle extract or a combination of them in 1:1 ratio. N. sativa honey was used in this study as it was found to be more potent on $P$. aeruginosa and $S$. aureus than other types of honey $^{23,24}$.

\section{Impregnated gauze preparation}

Standard sterile gauze 3 inch by 3 inch was dipped into different starch based mixtures till saturation and the excess solution was extruded by applying pressure. The hardening of the gel on the gauze was accomplished by refrigeration then the prepared impregnated gauzes were placed in sterile envelopes.

\section{Antibacterial efficacy}

$P$. aeruginosa and $S$. aureus were isolated from chronic wounds and tested for their antibiotic sensitivity. Antimicrobial activity test was carried out using agar diffusion method on Muller Hinton Agar plates ${ }^{25}$. Bacterial isolates were spread on plates, and then a hole was punched into plates with a diameter of $6 \mathrm{~mm}$. One hundred micro liter of each mixture was introduced into the hole and the plates were incubated for $24 \mathrm{~h}$ at $37^{\circ} \mathrm{C}$. The average of three cross sectional points of inhibition zone diameter was taken as the inhibition zone.

\section{RESULTS AND DISCUSSION}

Application of conventional antibiotics is becoming more difficult due to several problems especially antimicrobial resistance and side effects. This has reinforced the use of natural alternative agents to replace synthetic antimicrobials ${ }^{26}$. Accordingly, extensive research has been carried out in order to assess the antimicrobial activity of the natural extracts and different types of honey which showed the ability to inhibit the growth of various pathogenic microorganisms ${ }^{27}$.

Table 1: Antibiotic sensitivities of $P$. aeruginosa isolate.

\begin{tabular}{lcc}
\hline $\begin{array}{c}\text { Antibiotic } \\
\text { name }\end{array}$ & $\begin{array}{c}\text { Inhibition zone } \\
\text { diameter }(\mathbf{m m})\end{array}$ & Result \\
\hline Levofloxacin & 29 & Sensitive \\
Cefipime & 26 & Sensitive \\
Ceftazidime & 20 & Sensitive \\
Imipenem & 20 & Sensitive \\
Gentamycin & 15 & Intermediate \\
Doxycycline & 15 & Intermediate \\
Ceftriaxone & 10 & Resistant \\
Amoxicillin+ & No inhibition & Resistant \\
Clavulanic & zone & \\
acid & & \\
\hline
\end{tabular}

The antibiotic sensitivities of both $P$. aeruginosa and $S$. aureus isolated from chronic wounds are presented in Table 1 and Table 2. Table 3 shows the results of inhibition zone diameter of different prepared starch based mixtures on under-study microorganisms. Accordingly, the $N$. sativa honey mixture was the most potent against $P$. aeruginosa with an inhibition zone diameter of $18.1 \pm 0.3 \mathrm{~mm}$ similar to that of imipenem and ceftazidime, while the myrtle berries hydroalcoholic extract mixture was the most potent against $S$. aureus with an inhibition zone diameter of $18.4 \pm 0.5$ $\mathrm{mm}$ similar to that of tetracycline and chloramphenicol.

Table 2: Antibiotic sensitivities of $S$. aureus isolate.

\begin{tabular}{lcc}
\hline Antibiotic name & $\begin{array}{c}\text { Inhibition zone } \\
\text { diameter }(\mathbf{m m})\end{array}$ & Result \\
\hline Imipenem & 31 & Sensitive \\
Levofloxacin & 30 & Sensitive \\
Erythromycin & 23 & Sensitive \\
Meropenem & 22 & Sensitive \\
Tetracycline & 20 & Sensitive \\
Chloramphenicol & 19 & Intermediate \\
Cefotaxime & 13 & Resistant \\
Linezolid & 11 & Resistant \\
Cefazolin & 10 & Resistant \\
Cefaclor & No inhibition zone & Resistant \\
Ceftriaxone & No inhibition zone & Resistant \\
Cefdinir & No inhibition zone & Resistant \\
\hline
\end{tabular}

The positive and potent effect of myrtle extract on $S$. aureus in this study is consistent with the results obtained by Taheri et al., who had previously found that the concentration of $80 \mathrm{mg} / \mathrm{ml}$ of myrtle hydroalcoholic extract showed the greatest effect on the $S$. aureus bacterium with an inhibition zone diameter of $20.4 \pm 0.3 \mathrm{~mm}$. Same results were obtained by Salvagnini who studied the effect of the oil and 
ethanolic extact of myrtle on different strains and reported that the ethanolic extract of myrtle has a positive effect on $S$. aureus with $12 \mathrm{~mm}$ inhibition zone $^{28,29}$. Ghlamhsynyan Najjar et al., acknowledged that the activity of myrtle extract on $S$. aureus strain is partly due to the stimulation of free radicals ${ }^{30}$. The efficacy of honey against different types of microbes has been previously proved in different researches $^{23,24,31}$ and bacterial resistance ${ }^{15}$. Results of different researchers proved that honey was more potent against $P$. aeruginosa than $S$. aureus which is consistent with current results. Boateng and Nso Diunase found that the zone of inhibition values for $P$. aeruginosa ranged from $26.3 \pm 0.6 \mathrm{~mm}$ for Manuka honey to $34 \pm 2.0 \mathrm{~mm}$ for Cameroon standard honey, whilst the zones of inhibition against $S$. aureus was not more than $18.7 \pm 1.2 \mathrm{~mm}$ for Manuka honey ${ }^{32}$.

Table 3: Sensitivity of $P$. aeruginosa and $S$. aureus isolates against different mixtures.

\begin{tabular}{ccc}
\hline Mixture & \multicolumn{2}{c}{ Inhibition zone diameter $(\mathbf{m m})$} \\
\cline { 2 - 3 } & P. aeruginosa & S. aureus \\
\hline N. sativa honey & $18.1 \pm 0.3$ & $11.2 \pm 0.3$ \\
Myrtle extract & $15.3 \pm 0.2$ & $18.4 \pm 0.5$ \\
Myrtle extract with honey $1: 1$ & $13.6 \pm 0.4$ & $15.6 \pm 0.2$ \\
\hline
\end{tabular}

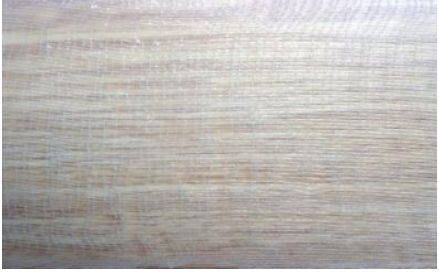

a

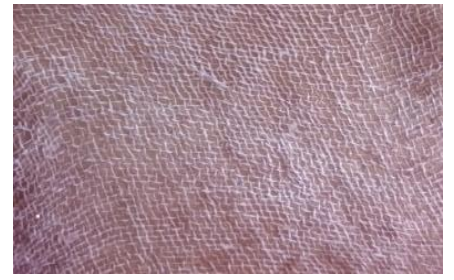

b

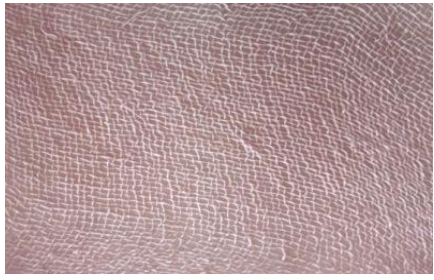

Figure 1: Impregnated gauze.

a. Impregnated gauze with $10 \mathrm{ml} \mathrm{N}$. sativa honey. b. Impregnated gauze with $10 \mathrm{ml}$ myrtle berries hydro-alcoholic extract. c. Impregnated gauze with $10 \mathrm{ml}$ N. sativa honey and myrtle berries hydro-alcoholic extract mixture (1:1).

As shown in Table 3 , the combination between $N$. sativa honey and myrtle berries extract was effective against both $P$. aeruginosa and $S$. aureus with a diameter zone of inhibition of $13.06 \pm 0.4 \mathrm{~mm}$ and $15.6 \pm 0.2 \mathrm{~mm}$, respectively. Dressings are a part of this process and are designed to be in contact with the wound, help in faster re-epithelialization, collagen synthesis and promote angiogenesis ${ }^{33}$. Bioactive wound dressings incorporated with antimicrobials are one of the most important modern wound dressings developed to play an important role in healing process compared with traditional wound dressings used only for covering the wound ${ }^{34}$. Commercially available antimicrobial dressings include honey-impregnated dressings, iodine-impregnated dressings, silverimpregnated dressings and chlorhexidine gauze dressing $^{35}$. Misirlioglu et al., used honey-impregnated gauze for the treatment of a split-thickness skin graft donor site. The gauze showed a lower sense of pain and faster epithelialization time than paraffin gauzes and saline-soaked gauzes ${ }^{36}$. In the UK, dressings impregnated with Manuka honey were successfully used in the wound care clinic ${ }^{37}$. Subrahmanyam et al., has shown in a randomized clinical study that residual scars decrease in patients treated with honeyimpregnated gauze compared with those treated with amniotic membrane ${ }^{38}$. It was also proved that wounds dressed with honey-impregnated gauze showed earlier healing compared with silver sulfadiazene dressing in burn patients ${ }^{39}$. The gauze can be cut to fit around the wound due to their soft elastic properties which provides easy application and removal without any damage. They also deliver active compounds with antiinflammatory and antimicrobial properties; and play an active role in the wound healing process. Starch based mixtures provide a moist environment in addition to a soothing and cooling effect.

\section{CONCLUSION}

Simple woven gauze although commonly used, they are known to be painful to remove, destructive to newly formed granulation tissue and provoke infection by leaving some fibers behind in the wound bed. A wide range of more appropriate dressings ensuring appropriate healing process has been available for a number of years such as medicated dressings. Plant extracts with antimicrobial and healing properties in addition were known to ancient cultures such as silver, honey and iodine are used for the preparation of medicated dressings. Although the perfect dressing is yet to be developed, wound dressings have evolved and further researches are still to be done.

\section{AUTHOR'S CONTRIBUTION}

The manuscript was carried out, written, and approved in collaboration with all authors.

\section{ACKNOWLEDGEMENTS}

The authors extend their thanks and appreciation to the Al-Andalus University for Medical Sciences, to provide necessary facilities for this work.

\section{CONFLICT OF INTEREST}

No conflict of interest associated with this work.

\section{REFERENCES}

1. Velnar T, Bailey T, Smrkolj V. The wound healing process: An overview of the cellular and molecular mechanisms. J Int Med Res 2009; 37(5):1528-1542.

https://doi.org/10.1177/147323000903700531 
2. Bowler PG, Duerden BI, Armstrong DG. Wound microbiology and associated approaches to wound management. Clin Microbiol Rev 2001; 14(2):244-269. https://doi.org/10.1128/CMR.14.2.244-269.2001

3. Boateng JS, Matthews KH, Stevens HN, Eccleston GM. Wound healing dressings and drug delivery systems: A review. J Pharm Sci 2008; 97(8):2892-2923 https://doi.org/10.1002/jps. 21210

4. Davis SC, Perez R. Cosmeceuticals and natural products: wound healing. Clin Dermatol 2009; 27(5):502-506 https://doi.org/10.1016/j.clindermatol.2009.05.015

5. Alipour G, Dashti S, Hosseinzadeh H. Review of pharmacological effects of Myrtus communis L. and its active constituents. Phytother Res 2014; 28:1125-1136. https://doi.org/10.1002/ptr.5122

6. Hosseinzadeh H, Khoshdel M, Ghorbani M. Antinociceptive, anti-inflammatory effects and acute toxicity of aqueous and ethanolic extracts of Myrtus communis L aerial parts in mice. J Acupunct Meridian Stud 2011; 4:242-247 PMID: 22946016

7. Chryssavgi G, Vassiliki P, Athanasios M, Kibouris T, Michael K. Essential oil composition of Pistacia lentiscus L. and Myrtus communis L.: evaluation of antioxidant capacity of methanolic extracts. Food Chem 2008; 107: 1120-1130.https://doi.org/10.1016/j.foodchem.2007.09.036

8. Sobel JD. Bacterial vaginosis. Ann Rev Med 2000; 51:349-56.

9. Mert T, Fafal T, Kivçak B, Öztürk HT. Antimicrobial and cytotoxic activities of Myrtus communis L. J Fac Pharm Ankara 2008; 37(3):191-199.

10. Shan B, Cai YZ, Brooks JD, Corke H. The in vitro antibacterial activity of dietary spice and medicinal herb extracts. Int J Food Microbiol 2007; 117:112-119. https://doi.org/10.1016/j.ijfoodmicro.2007.03.003

11. Akiyama H, Fijii K, Yamasaki O, Oono T, Iwatsuki K. Antibacterial action of several tannins against Staphylococcus aureus. J Antimicrob Chemother 2001; 48:487-491. https://doi.org/10.1093/jac/48.4.487

12. Serce S, Ercisli S, Sengul M, Gunduz K, Orhan E. Antioxidant activities and fatty acid composition of wild grown myrtle (Myrtus communis L.) fruits. Pharmacogn Mag 2010; 6:9-12. https://doi.org/10.4103/0973-1296.59960

13. Molan PC. The antibacterial activity of honey. 1. The nature of the antibacterial activity. Bee World 1992; 73:5-28. https://doi.org/10.1080/0005772X.1992.11099109

14. Abd-El Aal AM, El-Hadidy MR, El-Mashad NB, El-Sebaie AH. Antimicrobial effect of bee honey in comparison to antibiotics of organisms isolated from infected burns. Ann. Burns Fire Disast 2007; 20:83-88. PMID: 21991075

15. Carnwath R, Graham EM, Reynolds K, Pollock PJ. The antimicrobial activity of honey against common equine wound bacterial isolates. Vet J 2014; 199:110. https://doi.org/10.1016/j.tvjl.2013.07.003

16. Mãrghita LA, Dezmirean D, Adela M, Otilia B, Laura L, Bogdanov S. Physicochemical and bioactive properties of different floral origin honeys from Romania. Food Chemistry. 2009; 112(4):863-867. https://doi.org/10.1016/j.foodchem.2008.06.055

17. Van den Berg AJ, Van den Worm E, Van Ufford HC, Halkes $\mathrm{SB}$, Hoekstra MJ, Beukelman CJ. An in vitro examination of the antioxidant and anti-inflammatory properties of buckwheat honey. J Wound Care 2008; 17:172-178. https://doi.org/10.1080/21691401.2017.1337022

18. Lusby PE, Coombes AL, Wilkinson JM. Bactericidal activity of different honeys against pathogenic bacteria. Arch Med Res 2005; 36:464-467.https://doi.org/10.1016/j.arcmed.2005.03.038

19. Cooper RA, Molan PC, Harding KG. Honey and gram positive cocci of clinical significance in wounds. J Appl Microbiol 2002; 93:857-863. https://doi.org/10.1046/j.1365-2672.2002.01761.x

20. Cooper RA, Halas E, Molan PC. The efficacy of honey in inhibiting strains of Pseudomonas aeruginosa from infected burns. J Burn Care Rehabil 2002; 23:366-370. https://doi.org/10.1097/00004630-200211000-00002
21. Aksay S. Total Phenolic Content and Antioxidant Properties of Various Extracts of Myrtle (Myrtus communis L.) Berries. Çukurova J Agric Food Sci 2016; 31(2):43-50.

22. Famá L, Rojas AM, Goyanes S, Gerschenson L. Mechanical properties of tapioca-starch edible films containing sorbates. LWT 2004; 38:631-639. https://doi.org/10.1016/j.lwt.2004.07.024

23. Zam W, Harfouch R, Bittar S, Sayegh M. Antibacterial activity of various Syrian honey types against Pseudomonas aueruginosa. Research J Pharmacog Phytochem 2017; 9(2):73-76. https://doi.org/10.5958/0975-4385.2017.00013.9

24. Zam W, Harfouch R, Al Dwiri M, Khwanda R. AntiStaphylococcus aureus efficacy of six natural honey samples originated from Syria. Research J Pharmacog Phytochemistry, In Press. https://doi.org/10.5958/0975-4385.2018.00004.3

25. Shanker K, Krishna Mohan G, Bhagavan Raju M, Divya L, Sanjay B. Efficacy of leaves extract of Acacia nilotica against Pseudomonas aeruginosa with reference to Disc diffusion method. Res J Pharmacogand Phytochem 2014; 6(2):96-98.

26. Gortzi O, Lalas S, Chinou I, Tsaknis J. Re-evaluation of antimicrobial and antioxidant activity of Thymus spp. extracts before and after encapsulation in liposomes. J Food Protect 2006; 69:2998-3000. https://doi.org/10.4315/0362-028X-69.12.2998

27. Ayatollahi-Moosavi SA, Abdollahi H, Kazemipour N. Study of anti-dermatophyte effect of ten herbal methanolic extract. J Kerman Med Univ Sci 1996; 3(3):115-22. https://doi.org/10.1186/1472-6882-14-29

28. Taheri A, Seyfan A, Jalalinezhad S, Nasery F. Antibacterial Effect of $M$. communis hydroalcoholic extract on pathogenic bacteria. Zahedan J Res Med Sci 2013; 15(6):19-24.

29. Salvagnini LE, Oliveira JRS, Dos-Santos LE, et al. Brazilian J Pharmacognosy 2008; 18(2):241-244.

30. Gholamhoseinian-Najar A, Mansouri S, Rahighi S. Effect of sub-inhibitory concentrations of Myrtus communis leave extracts on the induction of free radicals in Staphylococcus aureus; A possible mechanism for the antibacterial action. Asian J Plant Sci 2009; 8(8):551-556. https://doi.org/10.3923/ajps.2009.551.556

31. Abd-ElAal AM, El-Hadidy MR, El-Mashad NB, El-Sebaie AH. Antimicrobial effect of bee honey in comparison to antibiotics of organisms isolated from infected burns. Ann Burns Fire Disasters 2007; 20:83-88.PMID: 21991075

32. Boateng J, Nso Diunase K. Comparing the antibacterial and functional properties of Cameroonian and Manuka honeys for potential wound healing-have we come full cycle in dealing with antibiotic resistance? Molecules 2015; 20:16068-16084. https://doi.org/10.3390/molecules200916068

33. Sarabahi S. Recent advances in topical wound care. Indian J Plast Surg 2012; 45(2):379-87. https://doi.org/10.4103/0970-0358.101321

34. Liesenfeld B, Moore D, Mikhaylova A, Vella J, Carr R, Schultz G, et al. Antimicrobial wound dressings- mechanism and function. In: Symposium on advanced wound care; 2009.

35. Dumville JC, O'Meara S, Deshpande S, Speak K. Alginate dressings for healing diabetic foot ulcers. Cochrane database of systematic review 2013; 6 .

36. Misirlioglu A, Eroglu S, Karacaoglan N, Akan M. Use of honey as an adjunct in the healing of split thickness skin graft donor site. Dermatol Surg 2003; 29:168-172. https://doi.org/10.1046/j.1524-4725.2003.29043.x

37. Visavadia BG, Honeysett J, Danford MH. Manuka honey dressing: an effective treatment for chronic wound infections. Br J Oral Maxillofac Surg 2008; 46(1):55-56. https://doi.org/10.1016/j.bjoms.2006.09.013

38. Subrahmanyam M. Honey-impregnated gauze versus amniotic membrane in the treatment of burns. Burns 1994; 20(4):331333. https://doi.org/10.1016/0305-4179(94)90061-2

39. Baghel PS, Shukla S, Mathur RK, Randa R. A comparative study to evaluate the effect of honey dressing and silver sulfadiazene dressing on wound healing in burn patients. Indian J Plast Surg 2009; 42(2):176-181. https://doi.org/10.4103/0970-0358.59276 